wittingly enough, to be sure-that, eight days before the answer of the Counch of The College of Surgeons to a conciliatory application, had been received, the ApothecArres Socrety was most earnestly solicited by them to join in asking for a conference with Sir JAMEs GraHam, with a view to obtain a SEPARATE charter of incorporation for the general practitioners. 'Than this, an act more perfidious to the profession was never perpetrated by the most corrupt and rotten of the Permanent Councils.

The feeling of disgust on the part of the Association against the Committee is becoming universal, and is fast pervading all ranks of the profession.

But that feeling is of too passive a nature for the existing crisis. Immediate action and combination are required. 'The thousands of our profession are, at this very moment, unrepresented. The Chairmen and Secretaries of all the Country Associations have been cast off from the Committee, in order, apparently, to provide for the introduction of a whole host of West-end Apothecaries. " Votes of Confidence !" Sickening, nauseating trash. What, we again ask, is the constitution of the lawless party nicknamed the "CoMmitreE" of Associated General Practitioners? "Votes of CONFIDENCE"-in antagonism with such facts-can produce no more effect on the minds of an intelligent profession, than could the frothiest surge of the ocean by playing upon a rock of adamant.

The facts are too speakingly eloquent to require rhetorical illustration or argument. Behold them :-

The Lawless Committee was elected, in a lump, late at night, by a small portion of a public meeting, without any previous notice, and by an assembly called for another purpose.

The members of the Committee had previously elected one another, upon the freest operation of the self-perpetuating principle.

The names of the members were not announced prior to their election, even to the small portion of the public meeting.

The proceedings of the Committee are all conducted with closed doors, and its organization, in point of numbers, stands thus:-

SIXTY-sIx members for LoNDon and the suburbs.*

Frve members who reside beyond the suburbs, and withis TEN MILES FROM LONDON.

ONe lives at MEdHurst, in Sussex, and that remarkable person is a member of the Court of Examiners of the Apothecaries' Company-a circumstance which sufficiently explains the cause of his selection.

Thus, the country surgeons of England, who have been labouring for twenty years to obtain a system of representation in medical government, are wholly excluded from occupying a single seat at the Board of this extraordinary Committee. Still, the funds of those surgeons have not been excluded from its coffers, and, notwithstanding the rejection of the provincial practitioners, those gentlemen constitute THREE-FoURTHS of the aggregate members of the Association.

Had we neglected to make these disclosures, we should have been guilty of a most scandalous duty to the members of our profession, and to the cause which we have unremittingly and zealously advocated for so long a period in this journal.

But what is to be done? Is there to be a Conferexce? Or, shall there be a Public Comsmrmen of members of the Association organized?

* Seventy-one members were formerly advertised, but the lawless committee have since discovered another, making the total seventy-two. The newly-found member also is resident in the metropolis.
These questions, we find, are to be discussed at a preliminary . meeting of gentlemen who are friends to one or both of the propositions, to be held at the Fremmasons' Tavern, GreatQueen-street, Lincoln's-inn-Fields, on Wednesday evening next; AprIL 23rd.

We know not what course will be adopted on that occasion, but of this we are assured, that fatal will be the consequence to medical interests unless some important steps be immediate ${ }^{7} y$ taken to counteract the disastrous and most culpable proceedings of the secret, self-elected, Lawless Committee.

WE intended to make a few remarks on the two important trials which have lately taken place at the Norfolk Lent Assizes, and which are reported at page 450 of the present number of The Lancet. Want of space, however, compels us to defer so doing until next week. In the meantime we direct the attention of our readers to those trials, which present many features of interest to the profession generally.

\section{THE LECTURES ON ORGANIC CHEMISTRY, BY PROFESSOR LIEBIG.}

My DEAR SIr,-With great regret I have to apologize to you and the readers of The LANCET, for the unavoidable interruption which has occurred in the publication of my Lectures on Organic Chemistry.

I have been compelled to remit my labour for a short time, in preparing the Lectures, in order to carry out some highly-im portant investigations, the results of which will, $I$ trust, possess great interest for your readers, and compensate them for a little delay in the completion of my course. As soon as those investigations are embodied on paper, I will forward them to you for publication, and I shall then be able to resume and proceed with the Lectures.-I remain, my dear Sir, yours truly,

\section{Justus LieBIG.}

To Thomas Wakley, Esq. M.P., Editor of The LANCET.

\section{REVIEWS.}

Anatomical and Pathological Observations. By John Goopsin, F.R.S.E, \&c., and Harry D. S. Goodsir, M.W.S., \&c. Edinburgh: Myles Macphail. 1845.

I $x$ is the essential peculiarity of works that contain original facts and opinions, to meet with opposition and severe criticism from those who have hitherto been unacquainted with them. We are all to a certain extent wedded to preconceived views, and these become more and more difficult to remove the longer they have been rooted in our minds. Hence every innovation is looked upon with jealousy, and all our acuteness is roused to attack the encroaching power. On the other hand, a judicious compilation, which sets forth, in a well-arranged form, the facts and opinions of others, is generally received with favour. We feel even more disposed to adopt what is new, when it comes to us in this second-hand form, and this, it would appear, simply because the novelty is somewhat diminished, and we are spared the labour of judging for ourselves. We could readily illustrate these propositions by a reference to the manner in which various works have been reviewed by the periodical press, but we shall content ourselves, at present, by alluding to the opposition which the facts and opinions of a Charles Bell and a Marshall Hall had to surmount.

We have been led into this train of thought by a careful 